Hays, M. T. (1966). Clin. Res. 14, 281.

Mitchell, W. D. (1965). F. Lab. clin. Med. 66, 677.

Myant, N. B. (1956). Clin. Sci. 15, 227.

Pinchera, A., MacGillivray, M. H., Crawford, J. D. \& Freeman, A. G. (I965). New Engl. J. Med. 273,83 .

Ripp, J. A. (1961). Am. F. Dis. Child. ro2, 106.

Shepard, T. H., Pyne, G. E., Kirschvink, J. F. \& McLean, M. (1960). New Engl. Y. Med. 262, 1099.

Taylor, S. (1954). Ұ. clin. Endocr. Metab. 14, 1412.

Van Middlesworth, L. (1957). Endocrinology 61, 570.

Wayne, E. J., Koutras, D. A. \& Alexander, W. D. (1964). Clinical Aspects of Iodine Metabolism. Blackwell: Oxford.

Wolff, J. (1964). Physiol. Rev. 44, 45.

\title{
The absorption of calcium from the intestine
}

\section{By E. Kodicek, Dunn Nutritional Laboratory, University of Cambridge and Medical Research Council}

From studies of loss of radiocalcium from the intestinal lumen of rats it was well known that the absorption of calcium occurs mainly in the proximal small intestine (Harrison \& Harrison, I951; Nicolaysen, r95I). A similar observation was made in the pig (Moore \& Tyler, I955). In the chick, according to Coates \& Holdsworth (I96I), however, calcium absorption appeared to occur over the whole length of the small intestine.

The recent advances in the use of everted sacs provided a useful tool to study the absorption of calcium. Thus Schachter \& Rosen (I959), Rasmussen (I959) and others could show that active transport of calcium against a concentration gradient can be achieved in everted sacs of the rat duodenum, but not of ileum, and the capacity of this transport mechanism decreased with distance from the pylorus. Anaerobic conditions, low temperature, dinitrophenol or other enzyme poisons effectively inhibited the active transport (Schachter \& Rosen, I959; Schachter, Dowdle \& Schenker, I960; Wassermann, 1960). Additions of glucose or fructose improved greatly the active absorption, while mannose, galactose, amino acids or some fatty acids had no marked effect (Schachter \& Rosen, 1959).

The age of the animals influenced the active transport in everted sacs; younger rats had a more efficient transport mechanism than older animals (Kimberg, Schachter \& Schenker, 196I). These effects were more marked when a low-calcium diet was given (Kimberg et al. 196I).

When rats were given a vitamin $\mathrm{D}$-deficient diet the active transport in everted sacs was significantly diminished and could be restored by in vivo dosing with vitamin D (Schachter \& Rosen, 1959; Dowdle, Schachter \& Schenker, I960; Kimberg et al. 196r). The response to vitamin D had a certain lag period of about 8-ro h. A biological assay based on the technique of everted sacs has been suggested by Schachter, Kimberg \& Schenker ( $196 \mathrm{I}$ ). Addition of vitamin D in vitro did not restore the impaired absorption, but recently Schachter, Kowarski \& Finklestein (1964) reported that cholecalciferol placed directly into in vivo loops of rat duodenum in vitamin D-deficient animals increased markedly the subsequent ( $5 \mathrm{~h}$ later) uptake 
of calcium by slices of the duodenal loop in vitro. This finding is interpreted that vitamin $\mathrm{D}$ acts directly on the intestinal tissues without prior activation in another organ. The avid uptake of $\left[{ }^{14} \mathrm{C}\right]$ vitamin $\mathrm{D}_{2}$ in intestinal tissue of deficient rats after intracardial injection would support the same conclusion (Kodicek, Cruickshank \& Ashby, I960; Kodicek, I965).

While the effect of vitamin $\mathrm{D}$ on the active transport mechanism is generally accepted, Harrison \& Harrison (1965) have postulated that the vitamin has also an influence on the permeability of the intestinal mucosa to calcium, as measured with in vitro preparations. Another interesting possibility has been advanced recently by Holdsworth (1965), namely that calcium is normally pumped out of the cell into the intestinal lumen and that vitamin $\mathrm{D}$ inhibits this process.

Parathyroid hormone appears to enhance the active transport of calcium across the intestinal mucosa. Rasmussen (1959) reported that after parathyroidectomy the ability of everted intestinal sacs to transfer calcium from the mucosal to the serosal side was somewhat reduced. Studies on plasma calcium concentrations following parathyroidectomy or administration of parathyroid hormone in absence or presence of vitamin $\mathrm{D}$ led several authors to the conclusion that a satisfactory vitamin $\mathrm{D}$ status was necessary to obtain the beneficial influence of parathyroid hormone on active calcium transfer (Rasmussen, DeLuca, Arnaud, Hawker \& von Stedingk, 1963; Harrison \& Harrison, 1964). On the other hand, Toverud (1964a,b) concluded that the effect of parathyroid hormone in the rat appeared to be independent of vitamin $\mathrm{D}$.

\section{Effect of vitamin $D$ on absorption of ${ }^{45}$ Ca from ligated loops of rat small intestine}

We have been interested in studying the transport of calcium across the mucosa of the rat small intestine by using ligated loops in vivo. Although many variable factors are introduced by this technique, the effects observed may be considered more physiological than those studied in vitro by the everted sac technique.

Solutions of ${ }^{45} \mathrm{Ca}$, from $0.3 \mathrm{I}$ to $125 \mathrm{mM}$, together with $50 \mathrm{mg}$ glucose, were introduced into ligated loops of the proximal or distal half of the small intestine of rats, starved overnight (Kodicek, Cruickshank, DeLuca \& Raisz, I964). The transport of ${ }^{45} \mathrm{Ca}$ from the proximal or distal portions of the small intestine was measured

Table I. Absorption of ${ }^{45} \mathrm{Ca}$ from ligated loops of small intestine of rachitic rats

\begin{tabular}{|c|c|c|c|c|c|}
\hline & & \multicolumn{2}{|c|}{$\begin{array}{l}\text { Percentage absorption from } \\
\text { proximal loop }\end{array}$} & \multicolumn{2}{|c|}{$\begin{array}{l}\text { Percentage absorption from } \\
\text { distal loop }\end{array}$} \\
\hline $\begin{array}{l}\text { concer } \\
\mu \mathrm{g} / \mathrm{ml}\end{array}$ & in loop & $\begin{array}{c}\text { Rachitic } \\
\text { rats } \\
(\%)\end{array}$ & $\begin{array}{c}\text { Rats given } \\
\text { vitamin D } \\
\text { supplement* } \\
(\%)\end{array}$ & $\begin{array}{c}\text { Rachitic } \\
\text { rats } \\
(\%)\end{array}$ & $\begin{array}{c}\text { Rats given } \\
\text { vitamin D } \\
\text { supplement } \\
(\%)\end{array}$ \\
\hline 12.5 & 0.313 & 57 & 85 & 34 & $5^{8}$ \\
\hline 25 & 0.625 & 60 & 72 & 29 & $5^{8}$ \\
\hline 50 & $\mathrm{r} \cdot 25$ & 62 & 74 & 27 & 56 \\
\hline 500 & $12 \cdot 5$ & $3^{6}$ & 62 & 20 & 36 \\
\hline 5000 & 125 & 7 & 8 & 6 & 6 \\
\hline
\end{tabular}

*600 i.u. vitamin $D_{2}$, twice by mouth in previous $48 \mathrm{~h}$ to rachitic rats; absorption time: 60 min (Kodicek et al. 1964). 
by determining the remaining ${ }^{45} \mathrm{Ca}$ in the loop after a suitable time interval and at the same time the appearance of radioactivity in the ash of the tibia was followed.

It was found (Table $I$ ) that, after $I \mathrm{~h}$, in the rats given vitamin $\mathrm{D}$ supplement, $74-85 \%$ in the proximal loop and $56-58 \%$ in the distal loop had been transported, when the concentration of calcium in the loop was below that of ionized calcium in the blood (about $\mathrm{I} \cdot 25 \mathrm{mM}$ ). At higher concentrations the percentage absorption was progressively reduced, until the absorptions were only 8 and $6 \%$, respectively, when $125 \mathrm{mM}{ }^{45} \mathrm{Ca}(5 \mathrm{mg} / \mathrm{ml})$ had been instilled. At the lowest concentration of ${ }^{45} \mathrm{Ca}(0.3 \mathrm{I} \mathrm{mM})$ the movement of the ions was against a concentration gradient, in both intestinal segments, suggesting an active transport mechanism. These findings are in agreement with those reported by Schachter $\&$ Rosen (1959) except that the latter authors found the activity mainly in the duodenal and jejunal portions.

The rate of absorption of $500 \mu \mathrm{g}{ }^{45} \mathrm{Ca}$ after $\mathrm{I} \mathrm{h}$ was greater in the proximal segment than in the distal segment (Fig. 1 ), but after $4 \mathrm{~h}$ the same proportion of calcium had been transported from both segments of the small intestine.

When similar investigations were made on young rachitic animals, which were given for 2-3 weeks the high-calcium, low-phosphorus diet of Steenbock \& Black (1925), the absorption of calcium was significantly lowered at calcium concentrations at or below $12.5 \mathrm{mM}$. At the highest concentration ( $25 \mathrm{mM}$ ) the deficiency of vitamin $\mathrm{D}$ had no effect on the calcium absorption (Table I). Thus at high concentrations of calcium in the intestinal lumen the transfer was not vitamin $\mathrm{D}$-dependent.

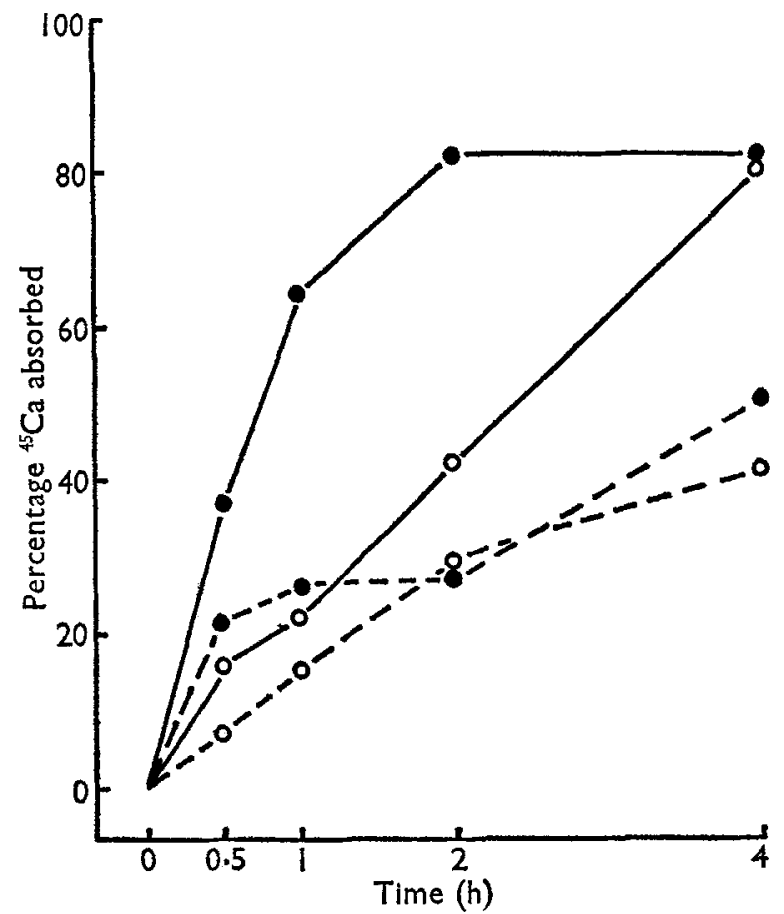

Fig. I. Time course of absorption of $500 \mu \mathrm{g}{ }^{45} \mathrm{Ca}$ from loops of upper or lower parts of small intestine of rachitic rats (- - ) and rats given vitamin $D_{2}$ supplement (- - ) (Kodicek et al. I $_{964}$ ). , loop of upper half of small intestine; $O$, loop of lower half of small intestine. 
When the transport of ${ }^{45} \mathrm{Ca}$ was followed for $4 \mathrm{~h}$, the rachitic animals showed a significantly lowered transport over the whole period, irrespective of the intestinal segment used.

The decreased transport efficiency of the deficient loops could be restored by oral administration of vitamin $D_{2}$ if the dose had been given at least $12 \mathrm{~h}$ before the loop experiment. A shorter period of $5 \mathrm{~h}$ had no effect nor had the instillation of the vitamin directly into the loop.

In previous experiments (Kodicek, 1963 ) it has been shown that up to about $5 \mathrm{~h}$ are required for the maximum accumulation of $\left[{ }^{14} \mathrm{C}\right]$ vitamin $\mathrm{D}_{2}$ in the mucosal cells of the small intestine, so that an appreciable lag period still remains during which there is no apparent effect of the vitamin. It might be presumed that during this period biochemical changes occur, such as elaboration or induction of a carrier system, which eventually increase the transport of calcium.

\section{Effect of parathyroidectomy on ${ }^{45} \mathrm{Ca}$ absorption from ligated loops of rat small intestine}

In young stock rats, parathyroidectomy, performed 7 days previously, decreased the ${ }^{45} \mathrm{Ca}$ absorption in both proximal and distal segments of the small intestine (Kodicek et al. 1964). This was particularly marked when the concentration of ${ }^{45} \mathrm{Ca}$ in the loop was either below or above that of the presumed ionized calcium level in blood (Table 2). The effect of the removal of parathyroid on lowering the serum calcium was already marked after i $\mathrm{h}$, but the decrease in calcium absorption from the intestinal loops occurred later, appearing consistently after $7^{2} \mathrm{~h}$.

Table 2. Absorption of ${ }^{45} \mathrm{Ca}$ from ligated loops of small intestine of stock rats after parathyroidectomy (Kodicek et al. I964)

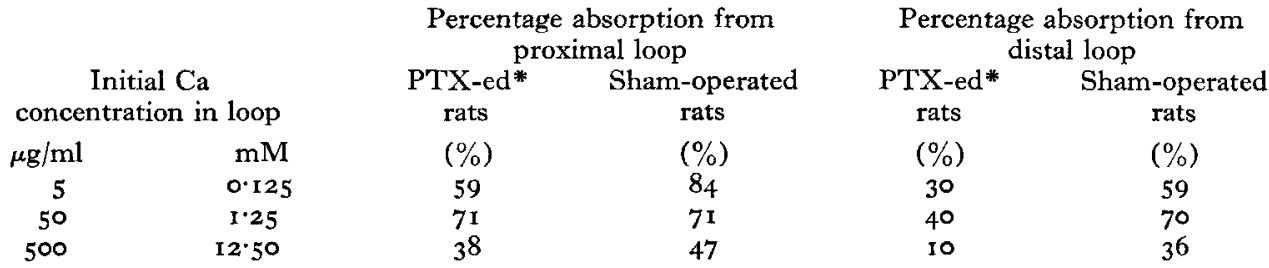

*Parathyroidectomized: the animals were operated on 7 days before the loop experiment; absorption time, $60 \mathrm{~min}$.

The results cited above are in agreement with the findings of Cramer (1963) who investigated the absorption of calcium from Thiry-Vella intestinal loops in the dog.

These results are consistent with the conclusions that vitamin $\mathrm{D}$ and possibly parathyroid hormone have an effect on the active transport of calcium. Recently, Thompson \& DeLuca (1964) and Hosoya, Fujimori \& Watanabe (1964) suggested that phospholipids might be involved in the calcium transfer in the intestine that is vitamin D-dependent. In our laboratory, no such direct connexion between phospholipids and vitamin D-dependent calcium transfer could be found (Lawson \& Kodicek, I966, in preparation). 
The recent reports on the effect of actinomycin D inhibition on calcium transport (Eisenstein \& Passavoy, r964; Zull, Czarnowska-Misztal \& DeLuca, r965, I966; Schachter \& Kowarski, I965; Norman, 1965) have focussed the attention on a possible involvement of a DNA- or RNA-linked protein synthesis which might be affected by vitamin $D$. The effect of vitamin $D$ on the incorporation of amino acids into bacterial proteins (McQuillen \& Kodicek, cited by McQuillen, 1958) after the incorporation had been inhibited by linoleic acid might be a model system simulating a similar reaction (Kodicek, 1965 ).

How far mitochondria or microsomes and calcium release from these subcellular particles, as postulated by Engström \& DeLuca (1962), De Luca, Engström \& Rasmussen (1962) and Snellgrove \& DeLuca (1965), is involved in the active transport of calcium across the cell has to await further research. The recent discovery of a protein in chick intestinal mucosa, which binds calcium and appears to be induced by administration of vitamin $\mathrm{D}$, might possibly be connected with the carrier system for calcium (Wassermann \& Taylor, 1963, 1966; Taylor \& Wasserman, I 965).

\section{REFERENCES}

Coates, M. E. \& Holdsworth, E. S. (I961). Br. F. Nutr. I5, I31.

Cramer, C. F. (1963). In Transfer of Calcium and Strontium Across Biological Membranes, p. 75. [R. H. Wassermann, editor.]. New York: Academic Press Inc.

Del.uca, H. F., Engström, G. W. \& Rasmussen, H. (1962). Proc. natn. Acad. Sci. U.S.A. 48, i604.

Dowdle, E. B., Schachter, D. \& Schenker, H. (1960). Am. F. Physiol. 198, 269.

Eisenstein, R. \& Passavoy, M. (1964). Proc. Soc. exp. Biol. Med. 117, 77.

Engström, G. W. \& DeLuca, H. F. (1962). F. biol. Chem. 237, PC974.

Harrison, H. E. \& Harrison, H. C. (I95I). F. biol. Chem. 188, 83 .

Harrison, H. E. \& Harrison, H. C. (I 964). Metabolism I3, 952.

Harrison, H. E. \& Harrison, H. C. (1965). Am. F. Physiol. 208, 370.

Holdsworth, E. S. (1965). Biochem. F. 96, 475.

Hosoya, N., Fujimori, A. \& Watanabe, T. (I964). Biochem. F., Tokyo 56, 613.

Kimberg, D. V., Schachter, D. \& Schenker, H. (1961). Am. F. Physiol. 200, 1256.

Kodicek, E. (1963). In Transfer of Calcium and Strontium Across Biological Membranes, p. I 85. [R. H. Wassermann, editor.] New York: Academic Press Inc.

Kodicek, E. (1965). Advances in Fluorine Research and Dental Caries Prevention. Vol. 3, p. 39. Oxford: Pergamon Press.

Kodicek, E., Cruickshank, E. M. \& Ashby, D. R. (1960). Biochem. F. 76, ${ }_{5}$ P.

Kodicek, E., Cruickshank, E. M., DeLuca, H. F. \& Raisz, L. P. (1964). In Bone and Tooth, p. 363. [H. J. J. Blackwood, editor.] Oxford: Pergammon Press.

McQuillen, K. (1958). Int. Congr. Biochem. Iv. Vienna 13, 306.

Moore, J. H. \& Tyler, C. (r955). Br. J. Nutr. 9, 8 r.

Nicolaysen, R. (195I). Acta physiol. scand. 22, 260.

Norman, A. W. (1965). Science, N.Y. 149, I84.

Rasmussen, H. (1959). Endocrinology 65, 517.

Rasmussen, H., DeLuca, H., Arnaud, C., Hawker, C. \& von Stedingk, M. (1963). F. clin. Invest. 42, $194^{\circ}$.

Schachter, D., Dowdle, E. B. \& Schenker, H. (1960). Am. F. Physiol. r98, 275.

Schachter, D., Kimberg, D. V. \& Schenker, H. (196r). Am. F. Physiol. 200, 1263.

Schachter, D. \& Kowarski, S. (1965). Bull. N.Y. Acad. Med. 4I, 24I.

Schachter, D., Kowarski, S. \& Finklestein, J. D. (1964). Science, N.Y. 143, 43.

Schachter, D. \& Rosen, S. M. (1959). Am. Y. Physiol. 196, 357.

Snellgrove, A. \& DeLuca, H. F. (1965). Archs Biochem. Biophys. III, 23.

Steenbock, H. \& Black, A. (r925). F. biol. Chem. 64, 263.

Taylor, A. N. \& Wassermann, R. H. (1965). Nature, Lond. 205, 248 ,

Thompson, V. W. \& DeLuca, H. F. (1964). F. biol. Chem. 239, 984.

Toverud, S. U. (1964a). Acta physiol. scand. 62, $39 \mathrm{I}$.

Toverud, S. U. (1964b). Acta physiol. scand. 62, Suppl. 235, p. I. 
Wassermann, R. H. (1960). Proc. Soc. exp. Biol. Med. 104, 92.

Wassermann, R. H. \& Taylor, A. N. (1963). Nature, Lond. 198, 30.

Wassermann, R. H. \& Taylor, A. N. (1966). Science, N.Y. r52, 79 r.

Zull, J. E., Czarnowska-Misztal, E. \& DeLuca, H. F. (1965). Science, N.Y. 149, I82.

Zull, J. E., Czarnowska-Misztal, E. \& DeLuca, H. F. (1966). Proc. natn. Acad. Sci. U.S.A. 55, I77. 